Marquette University

e-Publications@Marquette

Theology Faculty Research and Publications

Theology, Department of

$1-1-2016$

\title{
War As Morally Unintelligible: Sovereign Agency and the Limits of Kantian Autonomy
}

Philip J. Rossi

Marquette University, philip.rossi@marquette.edu

Accepted version. The Monist, Vol. 99, No. 1 (January 2016): 1-12. DOI. (C) 2016 The Author. Published by Oxford University Press on behalf of The Hegeler Institute. Used with permission. 


\title{
War as Morally Unintelligible: Sovereign Agency and the Limits of Kantian Autonomy
}

\author{
Philip J. Rossi \\ Theology Department, Marquette University \\ Milwaukee, WI
}

\begin{abstract}
Kant's treatment of war is usually discussed as part of his political philosophy or philosophy of history. In contrast, this essay locates these discussions in direct reference to major elements of his moral philosophy: autonomy, the categorical imperative, and the moral relationality of the kingdom of ends. Within this context, Kant's account of war, particularly in writings from the 1790s, can be read as affirming war as morally unintelligible: It is the expression of a collective withdrawal from the constitutive relationality of moral community. This results in a radical disparity in the exercise of moral autonomy by the sovereign agency of the state with respect to peace, on one hand, and with respect to war, on the other.
\end{abstract}

\section{War: Radical Challenge to Human Relationality}

Kant's discussions of war are most often located in texts that articulate the framework of his political philosophy 1 or sketch elements of his philosophy of history. ${ }^{2}$ In consequence, most accounts of his

The Monist, Vol 99, No. 1 (January 2016): pg. 1-12. DOI. This article is (C Oxford University Press and permission has been granted for this version to appear in e-Publications@Marquette. Oxford University Press does not grant permission for this article to be further copied/distributed or hosted elsewhere without the express permission from Oxford University Press. 
thinking about war tend to bypass questions about the location of war within the basic conceptual taxonomy of his moral philosophy. These accounts often concentrate instead on questions or topics that place war as a subject falling within the specific purview of political philosophy or the philosophy of history. They thus engage questions such as the extent to which Kant's discussions align him with the traditions of just war thinking, $\underline{3}$ constitute an element in his theory of political sovereignty, ${ }^{4}$ provide a basis for later accounts of an international cosmopolitan order, $\underline{5}$ or enable him to negotiate the pitfalls of a Hegelian dialectic that would make war morally instrumental to the achievement of the ultimate ends of human history. ${ }^{6}$

Pursuing these questions continues to yield useful results; for instance, recent work along these lines has drawn attention to Kant's initial adumbration of some elements anticipating the articulation of a set of post bellum conditions that are now often incorporated into just war theories and to the application of Kant's discussion to international interventions in the case of a 'failed state'. ${ }^{-1}$ My goal in this essay, however, is not directly to engage these questions or other ones arising primarily from the contexts of political philosophy and the philosophy of history, as instructive as those tasks may be. This essay's more fundamental concern arises from the fact that questions such as these (perhaps with the exception of ones similar to that posed in terms of Hegel's historical dialectic) seem to presume that 'war' functions conceptually in ways that can be unproblematically located with respect to the key concepts structuring Kant's moral philosophy. It is thus taken for granted that there is little need to provide a detailed moral account or analysis of war itself in terms of the fundamental conceptual structure of his moral philosophy. On this presumption, war is taken to be a course of action (or an array of various courses of action) that, at least in certain circumstances, could rightly be incorporated into the maxims of autonomous decisions made by moral agents in accord with the dictates of moral reason. $\underline{8}$

Over against such a presumption I will be arguing in this essay that Kant's writings, particularly those from the 1790s, provide substantial indications that war had started to take on a deeply problematic status in relation to the central concepts of his moral philosophy. War is no longer just one particularly complex moral issue

The Monist, Vol 99, No. 1 (January 2016): pg. 1-12. DOI. This article is (C) Oxford University Press and permission has been granted for this version to appear in e-Publications@Marquette. Oxford University Press does not grant permission for this article to be further copied/distributed or hosted elsewhere without the express permission from Oxford University Press. 
arising from conflicting claims to right that arise between states in the international arena and within which various courses of actions need to be weighed with respect to the demands of moral reason. It starts to become as well a key marker of the deep tensions inextricably embedded in the moral circumstances of humanity's efforts to extirpate its self-incurred propensity to evil, i.e., the propensity to invert the fundamental maxim for determining one's action: one subordinates the maxim that articulates the universally applicable demands of moral reason to a maxim that serves self-preference and self-exception in the face of reason's universal demand. This problematic status arises to the extent that Kant's discussions of war in these later writings indicate that he has begun to consider it as a social counterpart to the radical evil that, in Religion Within the Boundaries of Mere Reason, he had articulated as lying deep within the structure of autonomous moral agency. 9 War no longer presents itself simply as a possible object that can be determined to be fit (or unfit) for autonomous moral choice; it looms now, instead, as a thoroughly destructive social expression of the dynamics of the fundamental moral disorder of self-preference and self-exception that Kant calls 'radical evil'. The radical evil of war is that it completely undermines the human relationality and solidarity that, as the locus of elements formative of a universal moral community, provides the constitutive context for any and all agents' exercise of a genuine autonomy of mutually acknowledged freedom.

On the account I am proposing, the fundamental conceptual markers delimiting Kant's account of the moral use of reason-the autonomy of human moral agency, the categorical imperative as a demand of the practical use of reason, and the mutual respect that constitutes the universal moral community of autonomous agents that he terms 'the kingdom of ends'-are what provide the basis that eventually moves his thinking along a trajectory that requires war to be taken as a form of the moral unintelligibility that lies at the core of radical evil in both its personal and its social forms. Just as a maxim of self-preference marks out an individual agent's withdrawal from the mutuality of the moral community that provides intelligibility to the universality of reason's demand, war marks out a more far-reaching withdrawal from the constitutive relationality of moral community; it is a withdrawal that is collective in its scope. In the case of war, its unintelligibility lies in the depth and extent to which it destabilizes the

The Monist, Vol 99, No. 1 (January 2016): pg. 1-12. DOI. This article is (C) Oxford University Press and permission has been granted for this version to appear in e-Publications@Marquette. Oxford University Press does not grant permission for this article to be further copied/distributed or hosted elsewhere without the express permission from Oxford University Press. 
human solidarity and relationality formative of moral community; in consequence, it stands as a constant threat to undermine both the possibility and the efficacy of the exercise of autonomous human agency. The destabilization it effects is such that Kant regards war as a condition of unqualified lawlessness: it is the violently enacted denial of the human relationality requisite for the exercise of autonomous human agency. It is the social expression of a self-preferential maxim that, in the guise of protecting the rights and well-being of one's own civil society, allows, enjoins, and gives social approbation to the inflicting of deadly violence upon those fellow autonomous agents who, in a primal denial of human solidarity and relationality, are now deemed to be 'enemies'.

Two related texts that are particularly important for an initial charting of this trajectory in Kant's thinking can be found in "Perpetual Peace" and in the "Conclusion" to Part I of The Metaphysics of Morals. These texts are the ones in which Kant most directly and emphatically claims the status of a categorical imperative for the maxim 'there shall be no war': [Y] et reason, from the throne of the highest morally legislative power, delivers an absolute condemnation of war as a procedure for determining rights and, on the contrary, makes a condition of peace, which cannot be instituted or assured without a pact of nations among themselves, a direct duty. (ZeF GS 8:356/ET 327)Now morally practical reason pronounces in us its irresistible veto: there is to be no war, neither war between you and me in a state nor war between us as states, which, although they are internally in a lawful condition, are still externally (in relation to one another) in a lawless condition; for war is not the way in which everyone should seek his rights. (MS GS 6: 354/ET 491)

In these texts, the categorical imperative stands out, both substantively and rhetorically, as the central point of moral reference, but the two other central Kantian moral concepts, autonomy and mutual respect, each play a major role in the bold moral claim that I take him to be advancing here. With regard to the first, inasmuch as moral reason 'issues from its throne' an absolute condemnation of war incumbent upon all as a direct duty, this prohibition stands as a categorical imperative for all autonomous agents and its enactment thus requires the exercise of autonomous human agency. With regard to the second, the "irresistible veto" against war that morally practical

The Monist, Vol 99, No. 1 (January 2016): pg. 1-12. DOI. This article is (C) Oxford University Press and permission has been granted for this version to appear in e-Publications@Marquette. Oxford University Press does not grant permission for this article to be further copied/distributed or hosted elsewhere without the express permission from Oxford University Press. 
reason here pronounces as a categorical imperative bears upon the relation of respect "between you and me" that is required of all of us who stand in relation to one another in the "lawful condition" of right that constitutes the civil community of the state. This categorical imperative against war does not simply arise in virtue of the respect we owe one another as members of a kingdom of ends; its full focus in this instance is upon the affirmation and sustaining of that respect as the very condition for autonomous moral life. It is not merely a transgression of law; it is a dismantling of the very framework that makes law possible.

\section{Lawlessness and the Moral Unintelligibility of War}

What I have proposed so far is that, in his latest writings, Kant characterizes war in ways that suggest that it poses a singular moral challenge that is far more fundamental than whether there are reasons and circumstances that morally justify declaring and prosecuting a specific war. War stands, instead, as a radical challenge to the exercise of human autonomy inasmuch as it represents a fundamental undermining of the human relationality that provides autonomy with its constitutive context. At the same time, as Kant tries to articulate the nature of this challenge he returns to parts of the conceptual territory-in particular, the concept of 'the state of nature' as 'lawless' - that he had covered in earlier accounts of the origin of civil society that form a core element in his political philosophy. In returning to this territory, however, I do not see Kant significantly revising that core element with respect to the role it plays in his political philosophy, least of all with respect to its function in placing him within the broad tradition of social-contract thinking. Rather than revising his thinking about the contractual dynamics that structure civil society, his reconsideration of the moral status of war focuses, instead, on probing more thoroughly the circumstances and dynamics of the putative 'lawlessness' of such a state of nature with respect to its fundamental moral conceptuality and intelligibility.

In consequence, an important feature in the trajectory of Kant's thought toward affirming the moral unintelligibility of war is his claim that this categorical imperative prohibiting war has unconditional 
authority for all autonomous agents in even the lawless condition that constitutes a state of nature. While it remains the case that, as members of a particular civil society, autonomous agents are no longer in such a lawless condition with respect to their fellow citizens in that society, a state of nature continues to constitute the status of international relations as lawless prior to the establishment of a cosmopolitan world order that will make enduring peace possible. In other words, the categorical prohibition against war extends even into what Kant considers to be the remaining (and internationally pervasive) field of the lawless circumstances of the state of nature out of which reason had required the founding of human civil communities; this extension is required inasmuch as humans intentionally put themselves back into those lawless circumstances when, as nations, they contend against one another with deadly force in an explicitly undertaken state of war. Kant is thus claiming that this unconditioned law prohibiting war, which reason demands that we all follow, can and must be discerned by autonomous agents, even when they place themselves, as they needs must in declaring war and pursuing war, to be once again in an utterly lawless condition. In this case, however, the lawless condition marks the absence, not of a civil order internal to particular nations and their citizens, but of an international civil society constituted by an order of mutual recognition and respect among nations. In consequence, this categorical prohibition of war touches-though now on the macro scale of the human sociality formed by nation-to-nation relations-upon the very core of the human mutual relationality whose recognition provides fundamental form to the moral order constituted by and through autonomous human agency.

Kant, it should be noted, is quite aware of both the parallels and the differences that are involved between constituting the internal civil order for particular nations and constituting an international civil order among nations. A crucial difference between the two circumstances that Kant identifies as the state of nature is that in the case of exiting that condition for the sake of constituting the civic order for the governance of particular nations, the use of coercion to bring individual agents into becoming participants in that order is a necessary and justified limitation upon the exercise of their freedom; in the case of the international order, however, applying such coercion upon a sovereign nation cannot be similarly justified. $\underline{10}$ What Kant calls

The Monist, Vol 99, No. 1 (January 2016): pg. 1-12. DOI. This article is (C) Oxford University Press and permission has been granted for this version to appear in e-Publications@Marquette. Oxford University Press does not grant permission for this article to be further copied/distributed or hosted elsewhere without the express permission from Oxford University Press. 
in "Perpetual Peace" a "federalism of free states" (ZeF GS 8: 354/ET 325) comes about only in virtue of each state entering freely into such an association and thereby also freely assenting to the adjudicatory mechanisms that such a federation establishes to settle disputes that, in the international state of nature, would lead to war. Put in more direct terms, in entering into such a federation, a state freely renounces the only 'right' it seemed to have in the state of nature, i.e., the 'right to war' (MS GS 6: 343-46/ET 482-84). 11

There is an unmistakable irony, however, in Kant's account, and this irony has a direct bearing upon the substance of the claim that I have been making that in these later writings Kant begins to consider war morally unintelligible. The irony lies in the fact that the right that a nation 'renounces' in entering a federation of free states is not a right at all, since, on Kant's account, there is no basis for any right in a state of nature-unless one is willing to countenance, in the manner of Thrasymachus, the advantage of the stronger as the basis for right. The renunciation in question thus is not primarily an act of foregoing a basis for action upon which one once legitimately had a claim. It is rather the recognition that such a right is illusory: no state has ever had a legitimate basis for such a claim to begin with. In the lawless condition of the international state of nature, no legitimacy can be conferred on any claim to have or to exercise a 'right'. This illusory character of the right to war can thus be taken as the initial and perhaps the most fundamental marker of the moral unintelligibility of war.

The irony of renouncing a right that is not at all a right is further compounded, moreover, by the problem of identifying the agent (or agents) upon whom moral reason places the demand for such a renunciation/recognition and, concomitant with it, the agent (or agents) whose autonomy enables them to bring a sovereign state into a federation of free states. Put within the larger context of Kant's proposal for a cosmopolitan world order that provides the conditions for lasting peace among nations, this question of the agency responsible for the constitution of a cosmopolitan world order brings to light an unresolved tension between his account of moral autonomy and his account of political order; this tension bears upon the extent to which the moral unintelligibility of war, in undermining the relationality that gives form both to the moral and the political order, thereby also

The Monist, Vol 99, No. 1 (January 2016): pg. 1-12. DOI. This article is (C) Oxford University Press and permission has been granted for this version to appear in e-Publications@Marquette. Oxford University Press does not grant permission for this article to be further copied/distributed or hosted elsewhere without the express permission from Oxford University Press. 
undermines the possibility for the exercise of autonomous moral agency in the political order.

On my reading of the relevant texts, there are at least three points at which this tension is manifest. The first bears upon the identification of circumstances under which this categorical imperative prohibiting war becomes an operative demand upon human moral agents; the second bears upon the identification of the specific agents upon whom it is incumbent to act upon this demand; the third point, finally, bears upon the specification of the concrete actions required to enact this demand of our moral reason. With respect to each point, attention to Kant's account of the thoroughly lawless social circumstance of the international order of sovereign states within which human beings, through the agency of those sovereign states, go to war with one another is crucial: It provides the context from which Kant places singular responsibility upon the autonomous human agency of the sovereign, as a 'moral politician', for recognizing and enacting the categorical demand of the moral reason that "there shall be no war."

The central feature of that circumstance is that, prior to any actual declaration of war or any actual hostilities, it is already a state of war: The elements of the rights of nations are these: 1) states, considered in their external relation to one another are (like lawless savages) by nature in a nonrightful condition. This nonrightful condition is a condition of war (of the right of the stronger) even if it is not a condition of actual war and actual attacks being constantly made (hostilities). (MS GS 6: 344/ET 482)

Kant argues that within such a "nonrightful condition" the sole right that states have is a 'right to war', which functions in a tripartite manner: with respect to initiating war, conducting war, and ending a war (MS GS 6: 344-50/ET 482-87). As already noted, moreover, there is a curious character to his discussion of these functions, however, in that the right in question is fundamentally problematic: It lacks the fundamental social condition necessary for being exercised as a right, i.e., the lawful condition of the mutual recognition that, even as it became constitutive of civil society for individuals leaving the state of nature, was not extended to the relationship between and among states. One remark Kant makes in Metaphysics of Morals

The Monist, Vol 99, No. 1 (January 2016): pg. 1-12. DOI. This article is (C) Oxford University Press and permission has been granted for this version to appear in e-Publications@Marquette. Oxford University Press does not grant permission for this article to be further copied/distributed or hosted elsewhere without the express permission from Oxford University Press. 
suggests this lack of mutual recognition lies at the basis of the moral unintelligibility of war: "it is pleonastic, however, to speak of an unjust enemy in a state of nature; for a state of nature is itself a condition of injustice. A just enemy would be one that I would be doing wrong by resisting; but then he would also not be my enemy" (MS GS 6: 34950/ET 487).

"Perpetual Peace," by contrast, does not show similar rhetorical constraint in affirming the unintelligibility of war. In that text Kant makes the striking remark that "The concept of the right of nations as that of the right to go to war is, strictly speaking unintelligible [lä $\beta t$ sich eigentlich gar nicht denken] (since it is supposed to be a right to determine what is right not by universally valid external laws limiting the freedom of each but by unilateral maxims by force)" (ZeF GS 8: $356-57 /$ ET 328). He then reinforces the claim of unintelligibility by evoking the image with which he opened the essay-the Dutch innkeeper's sign that depicts a graveyard as the locus of 'perpetual peace'-as the referent for how one might ironically render intelligible such a right to go to war: "one would have to mean by it that it is quite right if human beings so disposed destroy one another and thus find perpetual peace in the vast grave that covers all the horrors of violence along with their authors" (ZeF GS 8: 357/ET 328).

The most important textual locus for articulating the tensions facing the exercise of autonomous moral agency in the face of the moral unintelligibility of war, however, can be found in Kant's treatment, in the first part of the Appendix to "Perpetual Peace," of the contrast between the 'moral politician' and the 'political moralist' in the manner in which they make decisions and wield power in directing affairs of state (ZeF GS 8: 370-80/ET 338-47). The 'moral politician' is Kant's designation for the political leader for whom "the concept of right is the limiting condition for politics," in contrast to the 'political moralist' who "frames a morals to suit the statesman's advantage" (ZeF GS 8: 372/ET 340). At stake in this distinction is the role of the exercise of moral autonomy, in the robust sense of properly heeding the demands of practical reason, in relation to the exercise of political authority and power in the radically lawless context that constitutes the international state of nature. Kant's discussion of the difference between these two forms of leadership and the relationship this difference has to the major coordinates of his account of the moral use

The Monist, Vol 99, No. 1 (January 2016): pg. 1-12. DOI. This article is (c) Oxford University Press and permission has been granted for this version to appear in e-Publications@Marquette. Oxford University Press does not grant permission for this article to be further copied/distributed or hosted elsewhere without the express permission from Oxford University Press. 
of reason will provide the basis for the final section of this essay, which will seek to articulate the radical character of the challenge that the moral unintelligibility of war presents to the autonomy of moral agents who are charged to exercise power and authority in the state.

\section{Peace, War, and the Autonomy of Sovereign Agency}

Although Kant does not identify the precise offices in the governance and administration of the state that he envisions the moral politician holding, the overall thrust of the arguments in "Perpetual Peace" that provide the context for this discussion lends plausibility to taking his discussion of political leadership to be directed to none other than the sovereign rulers of the nations of Europe. "Perpetual Peace" can thus be read as a primer for sovereigns providing them with basic instruction on how to be moral politicians. The likelihood that he has these rulers in mind as a principal audience for his essays rests, in the first instance, upon his expressed view that the republican principle of governance he favors, i.e., separation of legislative, executive, and judicial powers, in which those who legislate act as representative of an enfranchised adult male citizenry, functions most properly and justly under a monarch who wields the sovereign executive power. It is further supported, moreover, by particular indications in his argument that the policies most central to instituting an international regime for enduring peace, which encompass both the 'Preliminary' and the 'Definitive' articles for perpetual peace, can be effected only through a freely exercised agency, i.e., the agency of one individual who holds sovereign power.

Kant's placing of the locus of executive power in the hands of a single monarchical agent is, of course, fraught with implications for his political philosophy, particularly with respect to its relation to the political agency of the citizenry of the state. That, nonetheless, is not the primary issue for this discussion. With respect to the question of the moral unintelligibility of war, the most important aspect of Kant's account on which to focus is the character of the moral autonomy that is exercised by the sovereign as agent of the state both for war and for peace. By locating the agency of the state in a single agent, the sovereign, who is capable of acting autonomously in response to the

The Monist, Vol 99, No. 1 (January 2016): pg. 1-12. DOI. This article is (C) Oxford University Press and permission has been granted for this version to appear in e-Publications@Marquette. Oxford University Press does not grant permission for this article to be further copied/distributed or hosted elsewhere without the express permission from Oxford University Press. 
demand of practical reason, Kant's account satisfies a central condition of possibility that he has laid down for the emergence of an order of enduring peace: that a state has the capacity for freely leaving the international state of nature in order to enter a federation of free states and thus to enact autonomously the demand of the categorical imperative that there shall be no war. On Kant's account then, the state has this capacity for acting with moral freedom (autonomy)-at least with respect to establishing conditions for peace-precisely in virtue of the autonomously exercised agency of its sovereign: In this case the demand of moral reason that there shall be no war calls upon the moral freedom (autonomy) of the sovereign to be exercised as the moral freedom (autonomy) of the state.

It may be the case that in terms of the principles of sovereign authority within Kant's political philosophy, this exercise of a sovereign's moral autonomous agency in matters of state policy may be unproblematically characterized as also the exercise of the state's freedom. At the same time this attribution of both moral agency and a concomitant freedom of moral autonomy to the state may not be unproblematic in terms of the more fundamental conceptual coordinates of Kant's moral philosophy. As I indicate below in a concluding consideration on behalf of the claim that Kant's discussions of war move along a trajectory that points towards its moral unintelligibility, there is a radical disparity in the exercise of moral autonomy with respect to peace, on the one hand, and with respect to war, on the other.

The disparity is simple and fundamental: The freedom with which the sovereign and, concomitant with that, the state exercises its agency with respect to its establishing conditions for peace is a full exercise of moral autonomy. It is an unqualified response by that agency to the duty proposed by the categorical imperative that there shall be no war. Such a response, moreover, provides an instance in which an autonomous agent's adoption of the maxim, 'there shall be no war', as a universal law of nature, precisely in the persona of the sovereign agency of the state, can be understood as paradigmatically a "lawgiving by which alone a kingdom of ends is possible" (GMS GS 4: 434/ET 84). In this case, the kingdom of ends is given a concrete, though nonetheless partial, instantiation as fulfilling a necessary condition for the establishment of a federation of free states that has

The Monist, Vol 99, No. 1 (January 2016): pg. 1-12. DOI. This article is @ Oxford University Press and permission has been granted for this version to appear in e-Publications@Marquette. Oxford University Press does not grant permission for this article to be further copied/distributed or hosted elsewhere without the express permission from Oxford University Press. 
exited the lawless condition of the international state of nature. In contrast, as will be noted at the conclusion of this section, the exercise of agency by which a state goes to and conducts war stands as a polar opposite to such a full exercise of moral autonomy; exercising agency to go to war stands as an explicit denial of the moral reciprocity, i.e., the universal and mutual respect for one another's freedom in which members of a kingdom of ends stand to one another, that provides the necessary context for the exercise of any agent's autonomy.

Kant is quite clear that enduring peace comes about not by understanding it as a technical problem that can be resolved on the basis of a political expediency that seeks empirical harmonization of competing interests; it comes about instead by engaging it as a moral problem in which the duty that there shall be no war is recognized as a categorical imperative: ... the principle [i.e., so act that you can will that your maxim should become a universal law (whatever the end may be)] of the moral politician, for whom it [perpetual peace] is a moral problem (problema morale) is far removed from the other [technical principle of the political moralist] in its procedure for leading to perpetual peace, which is now wished for not only as a natural good but also as a condition arising from acknowledgment of duty. (ZeF GS 8: 377/ET 344)

As is the case with the exercise of an individual agent's autonomy in heeding the demands of moral reason, the full instantiation of a kingdom of ends is not accomplished by any single agent's exercise of autonomy, but requires the exercise of such autonomy by all agents. $\frac{12}{}$ Kant engages this issue in a number of his writings, most notably in Book Three of Religion Within the Boundaries of Mere Reason. In that text, he articulates its resolution in terms of a practical (moral) hope that has its focus on the establishment of an 'ethical commonwealth' that functions in many respects as a universal moral counterpart to the cosmopolitan world order that makes enduring peace among nations possible and for which a federation of free states is a necessary condition. One striking similarity between the establishment of such an ethical commonwealth and the establishment of a federation of free states is that entrance into eachin contrast to entrance into a civil society-cannot be coerced; it can only come about through the exercise of an agent's moral freedom. A second similarity is that in both instances Kant merely gestures

The Monist, Vol 99, No. 1 (January 2016): pg. 1-12. DOI. This article is (C Oxford University Press and permission has been granted for this version to appear in e-Publications@Marquette. Oxford University Press does not grant permission for this article to be further copied/distributed or hosted elsewhere without the express permission from Oxford University Press. 
towards engaging the question of what makes possible the convergence of the moral freedom of all autonomous agents that is required for the achievement of either of these definitive forms of human moral community. That gesture is an appeal to the hope for the convergence of the workings of nature and freedom that he takes to be grounded in moral reason, a hope that provides the content of his larger critical reconceptualization of the theological doctrine of providence.

An assessment of Kant's reconstruction of providence is important for determining the overall coherence of the account of the relation between nature and freedom that is central to his critical philosophy. $\underline{13}$ Such an assessment does not, however, directly bear upon the more immediate purpose of this section, which is to articulate the disparity between the exercise of moral autonomy on matters of war and peace as a marker of the moral unintelligibility of war. As has already been indicated, Kant is quite vigorous in his affirmation that acknowledgment of the categorical imperative that there shall be no war requires an agent to exercise moral autonomy, i.e., to recognize and to act upon it as a maxim for an unconditioned duty that has its basis in moral reason and is incumbent on all moral agents. This affirmation is re-enforced in Kant's discussion of the difference between the moral politician and the political moralist in which, as noted in the citation from "Perpetual Peace" two paragraphs above, he focuses precisely upon the duty to end war and to enter into an international order for establishing enduring peace as a prime instance of the fundamental difference between these two ways of exercising political leadership. Kant's discussion makes it clear that the moral politician is the only one who autonomously determines his course of action in leading the state; the political moralist, on the other hand, determines his course of action in ways that can be understood only as instances of heteronomy, i.e., as "subordinating principles to the end" (ZeF GS 8: 376/ET 376).

In contrast to the clarity with which he endorses the autonomy by which one is to pursue peace, Kant's silence is deafening with respect to the possibility that maxims by which one might justify engaging in war can be adopted autonomously as the dictates of moral reason. The possibility that entering into a state of war might be the subject for the exercise of moral autonomy does not even come under

The Monist, Vol 99, No. 1 (January 2016): pg. 1-12. DOI. This article is (C) Oxford University Press and permission has been granted for this version to appear in e-Publications@Marquette. Oxford University Press does not grant permission for this article to be further copied/distributed or hosted elsewhere without the express permission from Oxford University Press. 
consideration. This should not be surprising inasmuch as Kant equates the state of nature with a paradigmatically lawless condition: it places human beings at the farthest remove from the conditions of reciprocity and mutual respect for one another that give autonomy its moral intelligibility. In this condition the enmity that is war provides the default form by which humans engage one another; its 'form' is the chaos of a moral unintelligibility in which there is no standard to judge what is right in our dealings with one another except the successful exercise of naked power upon another. It is a condition in which the governing maxim for human conduct can only be: 'there shall be war.' Kant notes this when he observes In fact the political moralist can say that regent and people or nation and nation do each other no wrong when they attack each other by force or fraud, though they do wrong generally in that they deny all respect to the concept of right, which alone could found peace in perpetuity. (ZeF GS 8: 380/ET 346)

It is of no little significance that Kant makes this remark precisely from the perspective of the heteronomy of the political moralist. In keeping with the sharply ironic tone that permeates "Perpetual Peace," Kant is unsparing in his characterization of political moralists as agents whose guiding maxims for action are all heteronomous: they "frame morals to suit the statesman's advantage" (ZeF GS 8: 372/ET 340); by "glossing over political principles contrary to right" they "make improvement impossible and perpetuate, as far as they can, violations of right" and "they deal in machinations" (ZeF GS 8: 373/ET 341); they "approach the right of a state and the right of nations ... in a spirit of chicanery" and make use of "sophistical maxims" (ZeF GS 8: 374/ET 341-42). On Kant's account, the moral unintelligibility of war is patently obvious from the heteronomous perspective of the politics of power that guides or, perhaps more accurately, misguides the political moralist. Might Kant be proposing as well that such moral unintelligibility should be at least as patently obvious to his readers, especially to those sovereigns who have in their hands the power not just to exercise a specious 'right' to engage in war but also to exercise their moral freedom by heeding the actual and ever pressing duty to establish peace? 
NOT THE PUBLISHED VERSION; this is the author's final, peer-reviewed manuscript. The published version may be accessed by following the link in the citation at the bottom of the page.

\section{Footnotes}

${ }^{1}$ For instance, with regard to political philosophy, see TP: Über den Gemeinspruch: Das mag in der Theorie richtig sein, taugt aber nicht für die Praxis, GS 8: 273-313/ET: "On the Common Saying: That May Be Correct in Theory, But It Is of No Use in Practice," trans. Mary J. Gregor, in Practical Philosophy ed., Mary J. Gregor, The Cambridge Edition of the Works of Immanuel Kant (Cambridge: Cambridge University Press, 1996), 275-313, or MS: Die Metaphysik der Sitten, §§ 53-62, GS 6: 343-55/ET: The Metaphysics of Morals, in Practical Philosophy, trans. Mary J. Gregor, 343-55. Citations to Kant's works that are made in the text and notes will be in accord with the following abbreviations of their German titles, followed by the volume and pages numbers in GS (Kants Gessamelte Schriften, Ausgabe der Königlichen Preußichen Akademie der Wissenschaften, [Berlin 1902-]); these are then followed by the page numbers of English translations (ET) from the appropriate volume of The Cambridge Edition of the Works of Immanuel Kant from which the translations used in the text are taken.

GMS Grundlegung zur Metaphysik der Sitten GS 4. ET: Groundwork of the Metaphysics of Morals, trans. Mary J. Gregor, in Practical Philosophy, ed., Mary J. Gregor, The Cambridge Edition of the Works of Immanuel Kant (Cambridge: Cambridge University Press, 1996).

TP Über den Gemeinspruch: Das mag in der Theorie richtig sein, taugt aber nicht für die Praxis GS 8. ET: "On the Common Saying: That May Be Correct in Theory, But It Is of No Use in Practice," trans. Mary J. Gregor, in Practical Philosophy.

RVG Die Religion innerhalb der Grenzen der bloßen Vernunft GS 6. ET: Religion within the Boundaries of Mere Reason, trans. George Di Giovanni, in Religion and Rational Theology, ed. Allen W. Wood and George Di Giovanni, The Cambridge Edition of the Works of Immanuel Kant (Cambridge: Cambridge University Press, 1996)

MS Die Metaphysik der Sitten GS 6. ET: The Metaphysics of Morals, in Practical Philosophy, trans. Mary J. Gregor.

SF Der Streit der Fakultäten, Erneuerte Frage: Ob das menschliche Geschlecht im beständigen Fortschreiten zum Besseren sei GS 7. ET: The Conflict of the Faculties, Part II, "An Old Question Raised Again: Is the Human Race

The Monist, Vol 99, No. 1 (January 2016): pg. 1-12. DOI. This article is (C) Oxford University Press and permission has been granted for this version to appear in e-Publications@Marquette. Oxford University Press does not grant permission for this article to be further copied/distributed or hosted elsewhere without the express permission from Oxford University Press. 
NOT THE PUBLISHED VERSION; this is the author's final, peer-reviewed manuscript. The published version may be accessed by following the link in the citation at the bottom of the page.

Constantly Progressing?" trans. Mary J. Gregor and Robert Anchor, in Religion and Rational Theology.

ZeF Zum ewigen Frieden GS 8. ET: "Toward Perpetual Peace," trans. Mary J. Gregor, in Practical Philosophy.

${ }^{2}$ For instance, with regard to his philosophy of history, see ZeF: Zum ewigen Frieden GS 8: 341-86/ET "Toward Perpetual Peace," trans. Mary J. Gregor in Practical Philosophy, 317-51, or SF: Der Streit der Fakultäten: Zweiter Abschnitt GS 7: 79-94/ET The Conflict of the Faculties, Part II, "An Old Question Raised Again: Is the Human Race Constantly Progressing?" trans. by Mary J. Gregor and Robert Anchor, in Religion and Rational Theology, 297-309.

${ }^{3}$ For an extensive treatment and critique of views that place Kant's account within the just war tradition, see Howard Williams, Kant and the End of War: A Critique of Just War Theory (Basingstoke: Palgrave-Macmillan, 2012); a more compact overview of recent discussion of differing views of Kant's position in relation to just war thinking can be found in Thomas Mertens, "Kant and the Just War Tradition," From Just War to Modern Peace Ethics, ed. Heinz Gerhard Justenhoven and William A. Barbieri (Berlin: Walter de Gruyter, 2012), 231-47.

${ }^{4}$ See, for instance, Antonio Franceschet, Kant and Liberal Internationalism: Sovereignty, Justice, and Global Reform (New York: PalgraveMacmillan, 2002), 43-66.

${ }^{5}$ The most extensive recent account of the development and systematic import of Kant's cosmopolitanism is Pauline Kleingeld, Kant and Cosmopolitanism: The Philosophical Ideal of World Citizenship (Cambridge: Cambridge University Press, 2012); see 44-71 for a discussion that bears upon the role that international conflict and war play in the establishment of a cosmopolitan world.

${ }^{6} \mathrm{~A}$ succinct and quite illuminating instance of such a discussion is found in Allen W. Wood, Kant's Ethical Thought (Cambridge: Cambridge University Press, 1999), in his treatment of Kant's historical materialism, 244-49 and particularly in the accompanying endnote 19, 291-92. A related perspective placing Kant's discussions of international conflict in relation to Nietzsche's treatment of conflict is presented in Martine Prange, "Two Cosmopolitan Paradoxes: The Productive Role of 'Conflict' in Kant and Nietzsche's Cosmopolitan Theories," Kant und die Philosophie in weltbürgerlicher Absicht: Akten

The Monist, Vol 99, No. 1 (January 2016): pg. 1-12. DOI. This article is (C) Oxford University Press and permission has been granted for this version to appear in e-Publications@Marquette. Oxford University Press does not grant permission for this article to be further copied/distributed or hosted elsewhere without the express permission from Oxford University Press. 
NOT THE PUBLISHED VERSION; this is the author's final, peer-reviewed manuscript. The published version may be accessed by following the link in the citation at the bottom of the page.

des XI. Kant-Kongresses 2010, ed. Stefano Bacin, et al. (Berlin: Walter de Gruyter, 2013) Bd. 4, 816-25.

${ }^{7}$ For an instance of the first, see Brian Orend, "Jus Post Bellum: A Just War Theory Perspective," in Jus Post Bellum: Towards a Law of Transition From Conflict to Peace, eds. Carsten Stahn, Jann K. Kleffner (The Hague: T.M.C Asser Press, 2008), 31-52; on p. 34 he observes, "In my view, historically the first figure to offer us truly deep, systematic and forward-looking reflections on justice after war was the German Enlightenment philosopher Immanuel Kant (1724-1804)"; for an instance of the second see George Cavallar and August Reinsch, "Kant, Intervention and the 'Failed State'," Kantian Review 2 (1998), 91-106.

${ }^{8}$ Inasmuch as 'war' is appropriately construed as a social enterprise, the specific courses of action constitutive of the choice of 'going to war' or of 'waging war' can evidently be of different kinds and they can further be distinguished from each other in terms of the role different agents play with respect to these courses of action in the overall enterprise of war. So for the sovereign, the course of action to be considered is declaring war (and, conversely, agreeing to a peace treaty); for those in the military, it is preparing for and engaging in combat. Questions about who are the agents of war turn out to be among the vexing issues entangled in the larger question of whether-at least for Kantwar can be made morally intelligible.

${ }^{9}$ For a more detailed treatment of this relationship between war and radical evil see Philip J. Rossi, SJ, "War: The Social Form of Radical Evil," Kant und die Berliner Aufklärung: Akten des IX. Internationalen KantKongresses, Band 4, ed. Volker Gerhardt, Rolf-Peter Horstmann, and Ralph Schumacher (Berlin: Walter de Gruyter, 2001), 248-56.

${ }^{10}$ Three particularly relevant texts can be found in RGV GS 6: 93-100/ET 129-34; ZeF GS 8: 354-57/ET 325-28; and MS GS 6: 350-55/ET 487-92. There is a dispute among Kant interpreters regarding the extent to which Kant consistently maintains the view that coercion cannot be employed to bring about such a federation of states; for a useful overview see Kleingeld, Kant and Cosmopolitanism, 44-58.

${ }^{11}$ There is good evidence that Kant's own position with respect to the manner in which states enter, i.e., freely or through coercion, into the international federation he envisioned changes at various points in the development of his thinking about the international order. For a brief overview of these developments, see Kleingeld, Kant and

The Monist, Vol 99, No. 1 (January 2016): pg. 1-12. DOI. This article is (C) Oxford University Press and permission has been granted for this version to appear in e-Publications@Marquette. Oxford University Press does not grant permission for this article to be further copied/distributed or hosted elsewhere without the express permission from Oxford University Press. 
NOT THE PUBLISHED VERSION; this is the author's final, peer-reviewed manuscript. The published version may be accessed by following the link in the citation at the bottom of the page.

Cosmopolitanism, 65-71. The argument put forth in the current essay, however, is not based on attributing a definitive position to Kant on this particular matter, but rather on the articulating and taking seriously the conceptual implications that follow from the claims that he does put forth in a number of texts that entering such a federation is something that states do freely.

${ }^{12}$ Cf. GMS GS 4: 438-39/ET 87-88. Kant touches upon this same issue in a footnote to the first part of the Appendix in "Perpetual Peace," ZeF GS 8: $375-76 /$ ET 343.

${ }^{13}$ For an overview of the issues involved, see Pauline Kleingeld, "Nature or Providence? On the Theoretical and Moral Importance of Kant's Philosophy of History," American Catholic Philosophical Quarterly 75 (2001), 201-19.

The Monist, Vol 99, No. 1 (January 2016): pg. 1-12. DOI. This article is (C) Oxford University Press and permission has been granted for this version to appear in e-Publications@Marquette. Oxford University Press does not grant permission for this article to be further copied/distributed or hosted elsewhere without the express permission from Oxford University Press. 